\title{
Inženierzinātņu profesora Artura Tramdaha (1884-1970) intelektuālaìs un kultūrvēsturiskais mantojums Latvijas Universitātes Bibliotēkā
}

\author{
Intellectual and Cultural Heritage \\ of Professor of Civil Engineering Sciences \\ Arturs Tramdahs (1884-1970) at the Library \\ of the University of Latvia
}

\author{
Vēsma Klūga \\ LU Bibliotēka \\ Lielvārdes iela 24, Rīga, LV-1006 \\ E-pasts:vesma.kluga@lu.lv
}

Latvijas Universitātes (LU) Bibliotēkas krājumā atrodas vairāki dzelzsbetona zinātniskās pētniecības pamatlicēja Latvijā, ievērojamā dzelzsbetona konstrukciju speciālista, vairāku tiltu autora LU profesora Artura Tramdaha sarakstīti nozīmīgi darbi, kas izdoti līdz 1945. gadam. LU Bibliotēka glabā profesora A. Tramdaha rokraksta manuskriptu ar fotogrāfijām "Ziņojums Universitātes Padomei par ārzemju cel̦ojumu 1923. gada vasarā" par mācību komandējumu Vācijā un Šveicē, kur vinšs pētîja jaunākos atklājumus betona lietošanā būvniecībā. Rakstā sniegta informācija arī par profesora A. Tramdaha vairākkārtējiem grāmatu dāvinājumiem (kopumā ap 90 grāmatām) Inženierzinātņu fakultātes bibliotēkai. Nozīmīgs kultūrvēsturisks mantojums ir grāmatas ar profesora ierakstiem tajās.

Atslēgvārdi: Arturs Tramdahs, grāmatu dāvinājums, inženierzinātne, Inženierzinātṇu fakultātes bibliotēka, Latvijas Universitātes Bibliotēka.

Profesora Artura Tramdaha (1884-1970) darbība un mūža veikums jau ir pētīts un analizēts [5], tāpēc šī raksta mērķis ir iepazīstināt ar viņa atstātā mantojuma izpēti un saglabāšanu Latvijas Universitātes Bibliotēkā.

A. Tramdahs dzimis 1884. gada 14. septembrī Rubas pagastā Kurzemē. Pēc Jelgavas vidusskolas un reālskolas beigšanas viņš iestājas Rīgas Politehniskajā institūtā (RPI), ko ar uzslavu pabeidz 1910. gadā, iegūstot būvinženiera grādu. Tālākās darba gaitas uz neilgu laiku nākamo profesoru aizved uz Maskavu, kur viņš strādā pie pilsētas notekūdeņu attīrīšanas ietaises būvdarbiem. Atgriezies Rīgā, A. Tramdahs otrreiz iestājas RPI, lai iegūtu zināšanas tolaik pavisam jaunajā dzelzsbetona būvniecības nozarē. Līdz Pirmajam pasaules karam A. Tramdaha vadībā uzbūvēja Gogoḷa, Dzirnavu, Lāčplēša un Daugavpils ielas dzelzsbetona viaduktus, gājēju tuneli un Rīgas stacijas bagāžas telpu. No 1915. gada līdz 1918. gada pavasarim A. Tramdahs strādā Maskavā [5].

Pēc Latvijas Republikas nodibināšanas A. Tramdahs sāk darbu savas valsts labā - vispirms valsts dienestā [5], bet kopš 1919. gada 2. augusta kā Latvijas 
Augstskolas dibināšanas organizācijas komisijas loceklis. A. Tramdahs Inženierzinātņu fakultātes subkomitejas sastāvā izstrādā fakultātes mācību plānu, par paraugu ņemot labākās tehniskās augstskolas Eiropā [7].

No 1920. gada docents A. Tramdahs vada Masīvo un dzelzsbetona konstrukciju katedru, 1921. gadā viṇu ievēl par vecāko docentu, bet kopš 1934. gada pēc disertācijas "Ar elastīgu koka pāḷu ledgriežu izveidošanu saistīti pamatliekoši jautājumi” aizstāvēšanas - par profesoru. Ar pārtraukumiem no 1924. līdz 1930. gadam A. Tramdahs ir Inženierzinātņu fakultātes dekāns. Paralēli darbam LU A. Tramdahs vada arī būvniecības darbus. 1926. gadā A. Tramdahs apbalvots ar Triju Zvaigžņu ordeni. Vācu okupācijas laikā (1941-1944) profesors turpina darbu LU [5].

Otrajam pasaules karam sekojošajā padomju varas desmitgadē profesors turpina akadēmisko darbību LU, bet tas viņam kā bijušajam Latvijas brīvvalsts mācībspēkam, kas saṇēma nemitīgus pārmetumus par "nepareiziem uzskatiem”, nebija viegli. Laikraksts "Padomju Students" raksta: "Prof. A. Tramdahs inženierzinātṇu fakultātē jau vairākkārt asi kritizēts. 1949. g. martā žurnāls "Padomju Latvijas Boḷševiks" publicēja A. Vosa un N. Muravjova aso kritiku pret kosmopolītismu un buržuāzisko nacionālismu prof. A. Tramdaha darbā, uzskatos un 1935. g. publicētajās reakcionārajās brošūrās. Bet prof. A. Tramdahs nav ņēmis vērā kritiku, nav atzinis un nosodījis savas kḷūdas, nav atklāti paziṇojis tagadējo attieksmi pret saviem agrāk publicētajiem reakcionārajiem savārstījumiem un nav arī sagatavojis iespiešanai nevienu īstenu zinātnisku darbu vai rakstu. Ievērojot to, jāsecina, ka prof. A. Tramdahs nevēlas pildīt padomju zinātnieka pienākumus." [6]

Savukārt profesora students un subasistents Jānis Ātrens (1903-1998) atmin̄ās par A. Tramdahu raksta: "Viņa pārliecība bija, ka universitātes mācības spēkiem ir jāpalīdz studentiem studiju laikā pieradināties loǵiski domāt. Viņš savās lekcijās loti maz pieskārās rutīnas jautājumiem; par to bija rakstīts mācību grāmatās un tehnikas rokas grāmatās. Savās lekcijās viņš mēǵināja iztirzāt daudzās problēmas, kas radās, tehnikai strauji attīstoties. Katra lekcija bija kādas problēmas iztirzājums, iespējamais tehniskais atrisinājums, šo atrisinājumu kritika, lektora secinājumi, ieteikumi." [1]

Laikā no 1944. gada līdz pat atbrīvošanai no darba Latvijas Valsts universitātē (LVU) 1952. gadā A. Tramdahs profesora amatā strādā Inženierzinātņu fakultātē, līdz 1949. gada septembrim vada Tiltu būves katedru. Arī padomju varas gados paralēli pasniedzēja darbam savas zināšanas sniedz dažādām organizācijām, viṇu komandē arī uz Maskavu, lai pārn̦emtu Padomju Savienības dzelzsbetona konstrukciju būvniecības pieredzi. Nākamos 10 gadus pēc atbrīvošanas no darba LVU A. Tramdahs lasa lekcijas Latvijas Lauksaimniecības akadēmijā. A. Tramdahs miris 1970. gada 26. aprīlī un apglabāts Rīgā, 2. Meža kapos [5].

Lai arī J. Ātrens savās atmiņās raksta, ka "profesors brīvajā laikā bija aizņemts, studējot jaunākos publicējumus, kas parādījās vācu, franču un angḷu tehniskajos žurnālos [..]. Tā viņam pietrūka laika rakstīt mācību grāmatas, kas būtu atvieglinājušas studentiem mācību gaitas. Tehnisko grāmatu latviešu valodā toreiz tikpat kā nebija, tās bija vācu vai krievu valodās" [1], tomēr A. Tramdaha atstātais intelektuālais mantojums zinātnisko publikāciju veidā ir nozīmīgs un ievērojams.

A. Tramdahs publicējis vairāk nekā 60 zinātnisku rakstu tehniskajos žurnālos. Pirmās publikācijas tapušas par Latvijas dzelzceḷu līniju un tiltu atjaunošanas 
jautājumiem, pēc tam seko pētījumi par ledgriežņu konstrukcijām, šim jautājumam veltīta arī disertācija. 20. gs. 20.-30. gados publicē rakstus par dzelzsbetona konstrukciju veidiem būvniecībā, par cementa un betona īpašībām.

20. gadu beigās tapušais pētîjums "Koks kā būvmateriāls" (1928) apbalvots ar Kultūras fonda prēmiju. 30. gadu vidū profesors A. Tramdahs publicē savus nozīmīgākos darbus: "Par inženierdarinājumu estētiku" (1935), "Tehnika un inženierètika" (1935) [5], par kuru profesors Pauls Dāle ir teicis: "Ar lielu gandarījumu jāuzṇem prof. Dr. ing. A. Tramdaha vārdi: inženierim, kam jāorganizē dabas spēki, līdztekus saimnieciskajiem un sabiedriskajiem organizējumiem jāpazīst šo organizējumu elementi un par visu vairāk jāpazīst cilvēka garīgā konstitūcija.” [3]

LU Bibliotēkā glabājas divi unikāli A. Tramdaha manuskripti. Viens no tiem ir 1924. gadā sarakstītais "Ziņojums Universitātes Padomei par ārzemju celsojumu 1923. gada vasarā” [27]. Lai sekmētu mācībspēku kvalifikācijas pilnveidošanu un nodibinātu personīgus sakarus ar ārzemju zinātniekiem, LU savus pasniedzējus sūtīja zinātniskos komandējumos. Šādā mācību komandējumā uz Šveici un Vāciju 1923. gada vasarā devās arī docents A. Tramdahs, kur apmeklēja augstskolu laboratorijas Cīrihē, Karlsrūē, Drēzdenē, Vīnē, Berlīnē un tikās ar mācībspēkiem. Viñš apskatīja spēkstaciju un zvejniecības ostas būvniecības darbus un iepazinās ar betona lietošanu celtniecībā. Redzētais ir aprakstīts un atspogulots manuskriptā.

Tā ir rokraksta klade $(23 \times 28 \mathrm{~cm})$ cietos vākos ar 104 lapām, ar tekstu un mērījumu tabulām lapu vienā pusē un 33 ielīmētām melnbaltām fotogrāfijām. Darbs sastāv no ievada un vairākām daḷām. Ievadā autors īsi iepazīstina ar ceḷojuma mērḳi un paveikto. Tālāk atsevišşās nodaḷās autors sniedz betona vispārējo raksturojumu, atsevišksi apskata katru betona veidu, dodot to tehniskos parametrus, īpašības un lietojuma piemērus. Fotoattēli ilustrē dažādas betona gatavošanas ierīces un betonēšanas darba procesu.

"Latvijas inženieru un techniķu kongresa biroja žurnalā" publicētā informācija liecina, ka A. Tramdahs ar Eiropā redzēto iepaz̄istinājis jau pirms rakstiskās atskaites sagatavošanas: "Jaundibinātā Latvijas būvinženieru biedrība noturēja 21. decembrī 1923. g. savu pirmo sēdi universitātes inženierzinātñu fakultātes 12. klausītavā. Pēc īsa statūtu paskaidrojuma vadītājs deva vārdu doc. inž. A. Tramdaham, kurš referēja par betona uzpūšanu. Šo jaunāko betonēšanas veidu Tramdahs studējis Vakareiropā savā pagājušās vasaras ceḷojumā; referātu ilustrēja bagāts gaismas bilžu krājums, daļu no kura referents bija saṇēmis no Torkreta biedrības Berlīnē. Temats apgaismots pilnos apmēros sākot no 1908. gada, kad ungārs J. v. Vass Drezdenē atrada un patentēja savu izgudrojumu, līdz pēdējam 1923. gadam, kad minēto patentu turētājs atradis betona uzpūšanas un betona sviešanas (centrifugēšanas) savienošanu un to pielietojis lielo caurmēra cauruḷu izgatavošanai. Sēde bija loti kupli apmeklēta." [4] Turpat minēts, ka A. Tramdahs nākamajā sēdē stāstīs par betona liešanu.

Otrs manuskripts ir kopā ar docentu Edmundu Ziemeli (1880-1970) sastādītais “LU Inženierzinātṇu fakultātes 5 gadu darbības pārskats: (1919.-1924.)” [7]. Tas ir 99 lapu biezs manuskripts mašīnrakstā, drukāts ar melnu un zilu krāsu uz dažāda veida papīra. Daḷa teksta drukāta uz mazākām dažāda izmēra lapiṇām, ir arī teksts rokrakstā.

Saturā detalizēti aprakstīta fakultātes dibināšana, ir fakultātes dažādo komiteju un komisiju uzskaitījums hronoloǵiskā secībā, to uzdevumi, ievērojams apjoms ir 
veltīts mācībspēku biogrāfijai un darbībai, ieskaitot ārzemju mācību komandējumos redzēto un apgūto. Darbs ietver fakultātes nodaḷās un katedrās pasniedzamo priekšmetu sarakstus un studiju gaitas aprakstus. Manuskriptā sniegta informācija par bibliotēku, Ģeodēzijas institūtu, inženierzinātņu laboratoriju. Pielikumos uzrādīti fakultātes štatu saraksti; mācību plāni; projektu izstrādāšanas kārtības noteikumi; pierakstīšanās kārtība uz lekcijām un praktiskajiem darbiem; prasību minimums studentiem katrā studiju gadā; noteikumi par pārbaudījumiem un diplomdarba aizstāvēšanu; rasētavu un bibliotēkas lietošanas noteikumi; inženierzinātṇu doktora honoris causa grāda pieškiršanas kārtība. Manuskripts pilnā apjomā, bet ar vairāku teikumu konstrukcijas pārveidojumiem ir publicēts izdevumā "Latvijas Universitātes piecgadu darbības pārskats: 1919.-1924." [8]. Tabula atspoguḷo profesora A. Tramdaha darbus, kas glabājas LU Bibliotēkā.

Tabula

\section{LU Bibliotēkas krājumā esošie profesora A. Tramdaha darbi}

\begin{tabular}{|c|c|c|}
\hline \begin{tabular}{|c|} 
Nr. \\
p. k.
\end{tabular} & Autors & Nosaukums, izdošanas ziṇas \\
\hline 1. & Tramdahs, Arturs & $\begin{array}{l}\text { Latvijas Universitātes prof. Dr. art. h. c. Mārtiña Bīmaña } \\
70 \text { mūža gadu darbs / A. Tramdachs. Rīgā : [b.i.], 1934. } 7 \text { lpp. }\end{array}$ \\
\hline 2. & $\begin{array}{l}\text { Ziemelis, Edmunds } \\
\text { Tramdahs, Arturs }\end{array}$ & $\begin{array}{l}\text { Latvijas Universitāte.: LU Inženierzinātņu fakultātes } 5 \text { gadu } \\
\text { darbības pārskats : (1919.-1924.) / Ziemel̦a un Tramdacha } \\
\text { sastādīts. [Rīga, 1924]. [99] lp. }\end{array}$ \\
\hline 3. & Tramdahs, Arturs & $\begin{array}{l}\text { Mūra un betona caurlaidības novēršana / A. Tramdachs. } \\
\text { Rīga : Latvijas lauksaimniecības centrālbiedrības technikas } \\
\text { nodal̦a, } 1934 \text { (L. Audzes spiestuve) 30, [2] lpp. }\end{array}$ \\
\hline 4. & Tramdahs, Arturs & $\begin{array}{l}\text { Par inženierrdarinājumu aistētiku / Arturs Tramdachs. Rīga : } \\
\text { Valtera un Rapas akc. sab. izdevums, 1935. } 12 \text { lpp. }\end{array}$ \\
\hline 5. & Tramdahs, Arturs & $\begin{array}{l}\text { Par inženierkonstrukciju drošību / A. Tramdachs. Rīga : [b.i.], } \\
\text { 1933. 13, [1] lpp. }\end{array}$ \\
\hline 6. & Tramdahs, Arturs & $\begin{array}{l}\text { Par romanzementu un wiña leetoschanas kahrtibu / A. Tram- } \\
\text { dachs. Rīga : Latvijas Lauksaimniecības Centrālbiedrības } \\
\text { būvtehnikas birojs, 1932. } 20 \text { lpp. }\end{array}$ \\
\hline 7. & $\begin{array}{l}\text { Rozenšteins, Eižens } \\
\text { Tramdahs, Arturs }\end{array}$ & $\begin{array}{l}\text { Rozenšteins, E. (Eižens). Portlandcementa normas / E. Rozen- } \\
\text { šteins un A. Tramdachs. Rīga : [b.i.], } 1928 \text { (Valstspapīru } \\
\text { spiestuve) 27, [5] lpp. }\end{array}$ \\
\hline 8. & Tramdahs, Arturs & $\begin{array}{l}\text { Technika un inženier̦ētika / A. Tramdachs. Rīga : [b.i.], } 1935 . \\
32 \text { lpp. }\end{array}$ \\
\hline 9. & Tramdahs, Arturs & $\begin{array}{l}\text { Tuvīnu formulas tapu aplēsei / A. Tramdacha. [Rīga, } \\
\text { 1923]. [327.]-341. lpp. : il. }\end{array}$ \\
\hline 10. & Tramdahs, Arturs & $\begin{array}{l}\text { Vispārīgs pārskats par Rembates dolomītsmilšakmens pētī- } \\
\text { jumiem no būvmateriālu viedokḷa; Rembates dolomītsmilš- } \\
\text { akmens fizikāli-tehniskās īpašības un izmantojamība / Arturs } \\
\text { Tramdahs. Rīga : Zemes bagātību pētīsanas institūts, 1943. 10, } \\
\text { 181.-208. lpp. : il. }\end{array}$ \\
\hline 11. & Tramdahs, Arturs & $\begin{array}{l}\text { Ziņojums Universitātes Padomei par ārzemju cel̦ojumu } \\
\text { 1923. gada vasarā [manuskripts] / [Artur Tramdachs] [Rīga, } \\
\text { 1924]. } 104 \text { lp. : il., ielīm. fotogr., tab. }\end{array}$ \\
\hline
\end{tabular}


Inženierzinātṇu fakultātes bibliotēkas inventāru grāmatas [9] sniedz informāciju par profesora A. Tramdaha grāmatu dāvinājumiem un grāmatu iegādi no profesora pirkšanas ceḷā. Diemžēl daudzas dāvinātās grāmatas līdz mūsdienām dažādu iemeslu dēḷ nav saglabājušās.

Pirmās 22 grāmatas A. Tramdahs savas fakultātes bibliotēkai dāvinājis 1921. gadā - 21 grāmatu vācu valodā un vienu grāmatu latviešu valodā [10]. Informācija liecina, ka dāvinātās vācu inženiera Heinriha Leica (Heinrich Friedrich Leitz, 1886-1930) grāmatas grāmatas par dzelzsbetona materiālu izmantošanu būvniecībā Die Berechnung der frei aufliegenden, rechteckigen Platten (Berlin, 1914) [11] krājumā vairs nav, jo inventāru grāmatā pretī dāvinājuma ierakstam ir zīmogs ar tekstu "Grāmata izslēgta no inž.-zin. fak. bibliotēkas inventāra gr. ar 1941. g. 23. XII aktu Nr. 18.”. Tādu pašu likteni ir piedzīvojušas arī vairākas citas profesora dāvinātās grāmatas. 1924. gadā LU no A. Tramdaha iegādājās ievērojamā vācu inženiera profesora Emīla Morša (Emil Mörsch, 1872-1950) 710 lappušu biezo un bagātīgi ilustrēto grāmatu par dzelzsbetonu Der Eisenbetonbau : seine Theorie und Anwendung (Stuttgart, 1912) [14], arī š̄ grāmata izslēgta ar iepriekš minēto aktu.

1936. dāvinātais materiālu apkopojums "Latvijas tehniskās izglīî̄bas kongress 1934. gada 5. un 6. apr. Rīgas valsts tehnikumā” specfondā nonāca 1949. gada 23. martā [17]. Savukārt paša profesora 1934. gadā sarakstītais un fakultātes bibliotēkai dāvinātais "Latvijas Universitātes prof. Dr. art. h. c. Mārtiṇa Bīmaṇa 70 mūža gadu darbs" specfondā nonāca ar 1951. gada 1. decembra aktu [16], bet pie 1939. gadā dāvinātā rakstu krājuma "Latvijas zemes bagātību pētījumi" (1939) inventāru grāmatā ierakstīts: "Nodots specfondā ar aktu 1954. gada 11. septembrī".

Inženierzinātņu fakultāte savu nosaukumu saglabāja līdz 1951. gadam, kad 1. februārī tai pievienoja likvidēto Arhitektūras fakultāti un to nosauca par Inženierceltniecības fakultāti. Reorganizācijas rezultātā likvidēja vairākas agrākās specialitātes, piemēram, pilsētu cel̦u būvniecību, tiltu un tunel̦u būvniecību u. c. [2].

1958. gadā no LU tika nodalītas tehnisko zinātņu fakultātes, kas tika apvienotas atjaunotajā RPI, tāpēc ievērojams skaits tehniskā profila grāmatu no LU Bibliotēkas krājuma nonāca RPI. Informācija vēsta, ka 1923. gada 23. jūnijā A. Tramdahs savas fakultātes bibliotēkai ir dāvinājis futrālī ievietotu papīra logaritmisko lineālu [13], savukārt blakus ieraksts "Akts RPI 20. XII 1958” liecina, ka dāvinājums nonācis RPI. Tāpat arī dāvinātais paša sarakstītais darbs "Dzelzs daudzums stiegrotās betona konstrukcijās" nonācis RPI krājumā. Arī Kultūras fonda prēmiju sañēmusī un autora dāvinātā grāmata "Koks kā būvmateriāls" (1928) [15] 1958. gada 1. oktobrī nodota RPI.

1939. gada 6. jūlija ieraksts inventāru grāmatā [18] liecina, ka profesors Edgars Jakobi (1881-1964) Inženierzinātņu fakultātes bibliotēkai uzdāvinājis A. Tramdaha disertāciju mašīnrakstā "Ar elastīgu koka pāḷu ledgriežu izveidošanu saistīti pamatpaliekoši jautājumi” (1934), savukārt ar 1958. gada 1. oktobra aktu tā nodota RPI. Sazinoties ar RPI bibliotēku, tika saņemta informācija, ka RPI disertācijas manuskripta nav.

Diemžēl arī par A. Tramdaha manuskriptu “Tuvīnu formulas tapu aplēsei” [12] nav ziṇu, vai tas saglabājies, šo savu darbu autors bibliotēkai dāvinājis 1923. gadā, bet ar autora veltījuma ierakstu "L.U. Inž. zin. fak. bibliotēkai - A. Tramdahs, 22.10.[19]23.” [24] ir saglabājies tipogrāfijā iespiestais izdevums. 
"Vispārīgs pārskats par Rembates dolomītsmilšakmens pētījumiem no būvmateriālu viedokḷa; Rembates dolomītsmilšakmens fizikāli-tehniskās īpašības un izmantojamība" (1943) [19] ir pēdējā profesora dāvinātā grāmata, kas ar autora ierakstu "Inženier. zin. fak. bibliotēkai - Autors. 15.I.[19]44." [26] ir arī saglabājusies LU Bibliotēkas krājumā.

A. Tramdahs pavisam savas fakultātes bibliotēkai dāvinājis 89 grāmatas, no kurām vairāk nekā puse ir vācu valodā, bet 16 grāmatas LU no profesora ir iegādājusies pirkšanas cel̦ā [9].

Tieši grāmatas ar profesora A. Tramdaha veltījuma ierakstiem gan fakultātes bibliotēkai, gan saviem kolēgiem ir ar īpašu kultūrvēsturisku mantojuma nozīmi. Tās ir tikai dažas grāmatas, tāpēc vēl jo vērtīgākas.

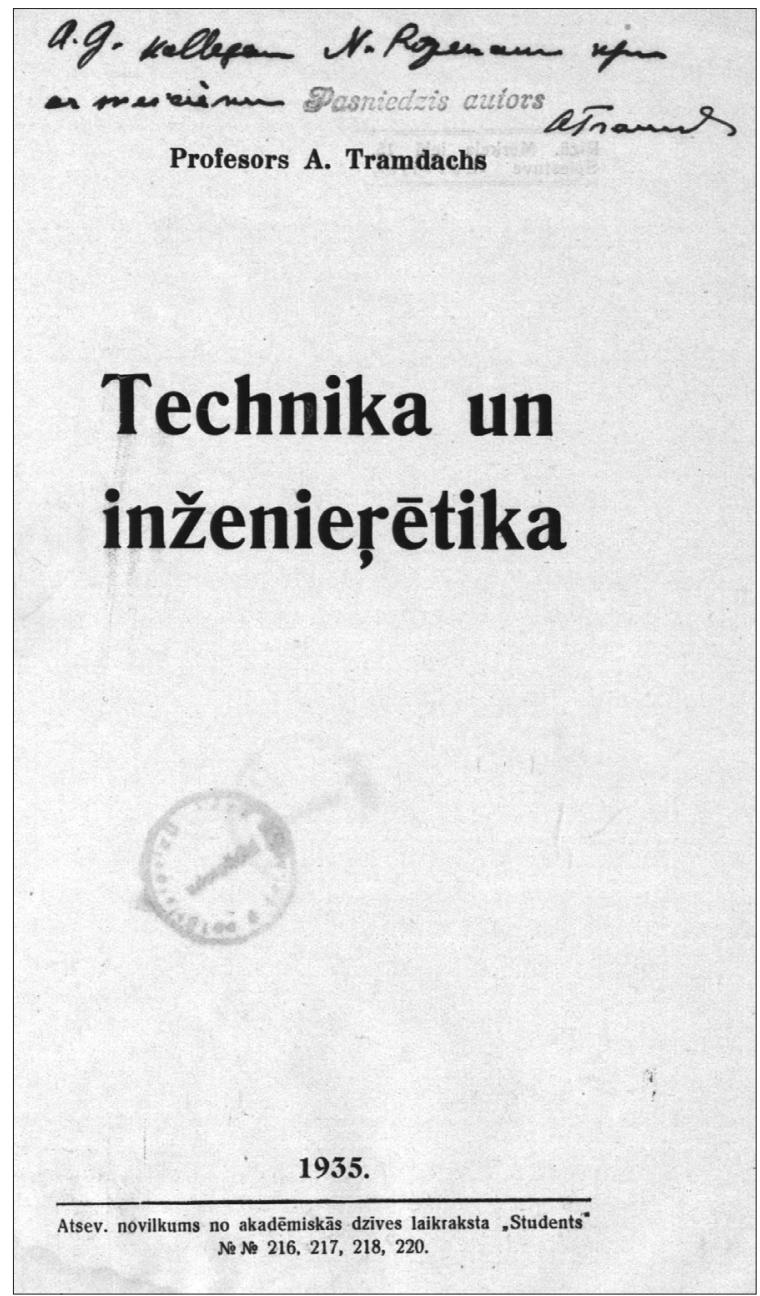

Attēls. Artura Tramdaha grāmata "Tehnika un inženierētika" (1935) 
1923. gadā atsevišksā "Latvijas Universitātes rakstu" iespiedumā izdoto darbu "Tuvīnu formulas tapu aplēsei" autors dāvinājis docentam Eduardam Jākobsonam (1896-1969), ierakstot “A. g. Ed. Jakobsona kungam. 22.10.[19]23. A. Tramdachs" [25]. Pēc gadu desmita kolēǵim dāvināta vēl viena grāmata, tas ir izdevums "Mūra un betona caurlaidības novēršana" (1934): “A. g. kollegam doc. Ed. Jakobsona kungam cienībā - A. Tramdachs" [20].

Savu grāmatu "Par inženierkonstrukciju drošību” (1933) ar ierakstu "A.g. kollegam doc. M. Vegnera kungam pasniedzis autors" [21] dāvinājis docentam Maksimiliānam Vegneram (1884-1962).

Savukārt grāmata "Tehnika un inženierētika" (1935) kā autora dāvinājums ar ierakstiem ir nonākusi pie profesoriem Nikolaja Rozenauera (1890-1970): “A.g. kollegam N. Rozenauera kungam ar sveicienu - A. Tramdahs" [22] un Franča Baloža (1882-1947): "Augsti godātam profesoram Fr. Baloža kungam ar cienību" [23]. Visi ieraksti veikti ar melnu tintes spalvu, tāpēc arī pēc daudziem gadu desmitiem ir skaidri izlasāmi.

Apzināt, saglabāt un popularizēt šīs grāmatas nozīmē saglabāt atmiṇu un izrādīt cieṇu savas tautas pagātnei un sasniegumiem.

\section{Kopsavilkums}

Rakstā sniegti galvenie profesora Artura Tramdaha (1884-1970) dzīvesgājuma dati un informācija par darbu Latvijas Universitātē (1919-1952). No LU Inženierzinātņu fakultātes bibliotēkas inventāru grāmatām apkopota un analizēta informācija par A. Tramdaha grāmatu dāvinājumiem Bibliotēkai. Grāmatas ar profesora veltījuma ierakstiem tajās ir nozīmīgs kultūrvēsturisks mantojums.

\section{VĒRES}

1. Ātrens J. Prof. Dr. Ing. Arturs Tramdachs. Akadēmiskā Dzīve, 1971, 13, 116.-117. lpp.

2. Augstākās tehniskās izglītības vēsture Latvijā. 2. daļa. Rīga: RTU, 2004. 543 lpp.

3. Dāle P. Psihologa darba ētikas pamatprincipi. Students, 1935, 223, 2.-3. lpp.

4. Iz biedrību dzīves. Latvijas Inženieru un Tehniķu Kongresa Biroja Žurnāls, 1924, 3-4, 113.-114. lpp.

5. Klētnieks J. Inženierzinātņu profesors Arturs Tramdahs (1884-1970). RTU Zinātniskie raksti. Humanitārās un sociālās zinātnes, 2005, 7, 95.-102. lpp.

6. Lasis A. Cīnna pret buržuāziskā nacionālisma izpaudumiem inženierzinātṇu fakultātē. Padomju Students, 1950, 10. okt., 1. lpp.

7. Latvijas Universitāte: LU Inženierzinātņu fakultātes 5 gadu darbības pārskats: (1919.-1924.). Ziemelis, Edmunds \& Tramdahs, Arturs. [1924]. [Rīga, 99] lp.

8. Latvijas Universitātes piecgadu darbības pārskats: 1919.-1924. Rīga: LU izdevums, 1925, 28.-83. lpp.

9. LU Inženierzinātn̦u fakultātes bibliotēkas inventāru grāmatas, Nr. 1-3. (1919-1954) (turpmāk - Inventāru grāmatas).

10. Inventāru grāmatas, Nr. 1, 31., 33., 35. 1pp.

11. Turpat, 31. lpp.

12. Turpat, 127. lpp.

13. Turpat, 141. lpp.

14. Turpat, 181. lpp.

15. Turpat, Nr. 2, 19. lpp. 
16. Turpat, 99. 1pp.

17. Turpat, 114. lpp.

18. Turpat, Nr. 3, 8. lpp.

19. Turpat, 79. lpp.

20. Tramdahs A. 1934. Mūra un betona caurlaidības novēršana. Rīga: Latvijas lauksaimniecības centrālbiedrības technikas nodaḷa, 30, [2] lpp. (inv. Nr. 1952:47034).

21. Tramdahs A. 1933. Par inženierkonstrukciju drošǐbu. [B. i.], Rīga. 13, [1] lpp. (inv. Nr. 1952:47034).

22. Tramdahs A. 1935. Technika un inženierēetika. [B. i.], Rīga. 32 lpp. (inv. Nr. 1952:31067).

23. Tramdahs A. 1935. Technika un inženierēetika. [B. i.], Rīga. 32 lpp. (inv. Nr. 1952:31065).

24. Tramdahs A. [1923]. Tuvīnu formulas tapu aplēsei. [Rīga]. [327.]-341. lpp.: il. (inv. Nr. Sp. 1952:6651).

25. Tramdahs A. [1923]. Tuvīnu formulas tapu aplēsei. [Rīga]. [327.]-341. lpp.: il. (inv. Nr. 1952:31060).

26. Tramdahs A. 1943. Vispārīgs pārskats par Rembates dolomītsmilšakmens pētījumiem no būvmateriālu viedokḷa. Rembates dolomītsmilšakmens fizikāli-tehniskās ìpašības un izmantojamība. Rīga: Zemes bagātību pêtīšanas institūts, [38] lpp. (inv. Nr. Sp. 1952:6650).

27. Tramdahs A. 1924. Ziņojums Universitātes Padomei par ārzemju ceļojumu 1923. gada vasarā [manuskripts]. [Rīga]. 104 lp.: il., ielīm. fotogr., tab.

\section{Summary}

The article presents the main data about Professor of Civil Engineering Arturs Tramdahs (1884-1970) life and his work at the University of Latvia (1919-1952). The inventory books of the Library of the Engineering Faculty store valuable information about his book donations to the Library - 89 books in total. These books with inscriptions and autographs by the Professor have a special cultural and historical meaning.

Keywords: Arturs Tramdahs, book donations, civil engineering, Library of the Faculty of Engineering, Library of the University of Latvia. 